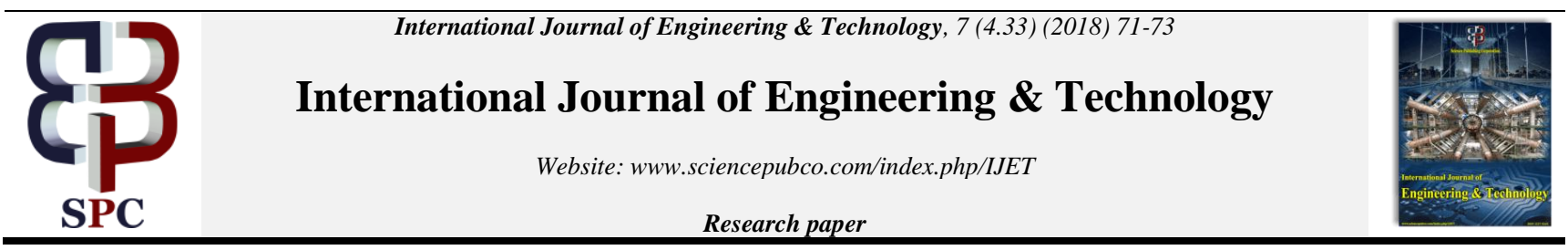

\title{
Macroeconomic Risk Factor in Fuzzy Present Value of Highway Development
}

\author{
Siti Salihah Shaffie ${ }^{1,2 *}$, Saiful Hafizah Jaaman ${ }^{1}$, Daud Mohamad ${ }^{4}$ \\ ${ }^{1}$ School of Mathematical Sciences, Faculty of Science and Technology, University Kebangsaan Malaysia, 43600, Bangi, Selangor, \\ Malaysia \\ ${ }^{2}$ Faculty of Computer and Mathematical Sciences, Universiti Teknologi MARA, Perak Branch, Tapah Campus, Tapah Road, 35400 \\ Perak, Malaysia \\ ${ }^{3}$ Faculty of Computer and Mathematical Sciences, Universiti Teknologi MARA, 40450 Shah Alam, Selangor, Malaysia \\ *Corresponding author E-mail: sitis064@perak.uitm.edu.my
}

\begin{abstract}
Highway developments are the backbone for the society and economic growth. It is part of the capital investment in infrastructure developments that require high spending, long term commitment and prognosticated with numbers of risks. This is because the investment is associated with uncertainty and vagueness due to long term duration of construction and operation of the project. Hence, the valuation of the investment requires accommodated model to present more accurate estimation of the project. This study proposed to evaluate fuzzy present value of a highway project with anticipated risk assessment in its valuation using fuzzy present value. The risk assessment is part of the estimation of fuzzy cash flow to represent better present value of the project. The results show an estimated value comprise with risk assessment of macroeconomic factor to portray better estimation that can assist decision maker to make decision towards the project.
\end{abstract}

Keywords: Fuzzy cash flow; Fuzzy number; Fuzzy present value; Risk assessment.

\section{Introduction}

Capital investment is the backbone for social and economic development. However, this kind of investment requires high spending, long term commitment and anticipated with various numbers of risks. In year 2001-2005, Malaysia spent approximately RM 64.12 billion in capital investment mainly in infrastructure development [1]. Roads development is one of infrastructure development that demand large amount of financial allocation. As total amoun spent in year 2001-2005, RM 180 million needed for roads development alone. Due to high financial commitment, many countries including Malaysia adopted the built-operate-transfer (BOT) scheme for roads development. BOT is an agreement between public and private sectors where the private sector is required to finance, design, build, operate and maintain the facility. In this agreement, private sector can collect reasonable profit from users for a certain period called concession period. After a specified concession period, the facility is handed over to the government [2].

Studies showed that roads developments are associated with numbers of risks [3-4]. Hence, risk assessment is extremely important to the success implementation of BOT project. The purpose of risk assessment is to quantify the common risks occurred. Risk assessment will help to determine the severity impact and compose the most significant factor that affect the project [5]. In risk assessment, each risk involved in BOT project will be identified to determine most common risk anticipated during construction and operation of the project. Next, the risk will be ranked and assessed to ascertain value of the risk to the valuation of the project. This study proposes to estimate fuzzy present value with macroeconomic risk factor assessment. The identified and assesses risk will be comprised to the valuation of the project to prevail the project estimation.

\section{Risk Assessment}

The purpose of risk assessment is to identify and quantify the most common risks occurred in the project. Risk assessment help to determine the severity impact of each risk involve, which ultimately strike the project's valuation [5]. Table 1 presented most commonly risk occurred in infrastructure development in Malaysia.

This study adopted model used by [6], to determine the weightage of each risk identified in Table 1 . This model presented better judgement of severity impact of the risk in the project. The severity impact was normalized $[0,1]$ which signify greater impact for risk that has value closer to 1 and less impact for risk close to 0 . Model (1) is used.

$$
\mathrm{W}_{\mathrm{i}}=\frac{\mathrm{M}_{\mathrm{i}}}{\sum_{\mathrm{i}=1}^{\mathrm{n}} \mathrm{M}_{\mathrm{i}}}
$$

where

$$
\begin{array}{ll}
\mathrm{W}_{\mathrm{i}} & : \text { weightage of each risk group } \\
\mathrm{M}_{\mathrm{i}} & : \text { mean of particular risk group } \\
\sum_{\mathrm{i}=1}^{n} \mathrm{M}_{\mathrm{i}} & : \text { summation of mean of all risks groups }
\end{array}
$$


There were seven risks identified and ranked to show significant anticipation on highway development. Operation and maintenance risk signify the highest risk in the development. According to [7], there are few factors contributed to higher maintenance in BOT project in Malaysia, namely over-loaded freight transportation, change of road networks and traffic congestion. Macroeconomic factor is the forth in the row. Microeconomic risk considered risky due to fluctuation of interest and inflation rate.

Table 1: Risk Severity Impact

\begin{tabular}{|c|c|c|}
\hline \multirow{2}{*}{} & \multicolumn{2}{|c|}{ Risk Severity Impact } \\
\cline { 2 - 3 } & Risk Identified & Weightage \\
\hline 1. & Operation and maintenance & 0.57 \\
\hline 2. & Construction & 0.21 \\
\hline 3. & Staffing & 019 \\
\hline 4. & Macroeconomic & 0.17 \\
\hline 5. & Political & 0.17 \\
\hline 6. & Market risk & 0.15 \\
\hline 7. & Natural & 0.13 \\
\hline
\end{tabular}

\section{Macroeconomic Risk in Fuzzy Present Val- ue}

Fuzzy in financial mathematics started around 1987, proposed by [8], to estimate present value for long time period project. In this study, the present value is said to represent the real value of the project due to its consideration of other extraneous factor that happen during the operation of the project. One of the factor that changes in time is the macroeconomic factor.

Model proposed by [8] have been extended in many studies. It has been widely used for projects valuation to evaluate big scale and long duration project investment [9-11].

Fuzzy element colligates to net present value model capable to extend the given result in the range that will give flexible judgement to the decision maker in making the decisions.

The classical net present value model presented by net cash flow and the annual interest rate [12].

$$
\mathrm{NPV}=-\mathrm{C}_{0}+\sum_{\mathrm{i}=1}^{\mathrm{n}} \frac{\mathrm{CF}_{\mathrm{i}}}{(1+\mathrm{r})^{\mathrm{i}}}
$$

This study divided 26 years of toll collection into seven subperiods. The divisions into seven sub-periods of GDP growth illustrated the fluctuation in toll collection based on the economic scenario. Each sub-period represents single triangular fuzzy number.

Fuzz number allows crisp value of annual cash flows of the project to the triangular fuzzy number with various degrees of membership. Fuzzy number is an element of Fuzzy Set theory developed by [13].

\section{Definition 1.}

A fuzzy set $\tilde{A}$ in $X$ is a set of ordered pairs,

$$
\tilde{\mathrm{A}}=\left\{\mathrm{x}, \mu_{\tilde{\mathrm{A}}}(\mathrm{x}) \mid \mathrm{x} \in \mathrm{X}\right\}
$$

where $\mu_{\tilde{\mathrm{A}}}(\mathrm{x})$ : degree of membership function of $\mathrm{x}$ in $\tilde{\mathrm{A}}$. The membership function is in the closed interval $[0,1]$ and $\tilde{A}$ is a normal fuzzy set.

Definition 2.

Present value of projects' valuation

$$
\mathrm{PV}=\sum_{\mathrm{t}=1}^{7} \frac{\mathrm{CF}_{\mathrm{i}}}{\left(1+\mathrm{r}_{\mathrm{i}}\right)^{\mathrm{i}}}
$$

where

$$
\begin{aligned}
& \mathrm{PV}: \text { Present value } \\
& \mathrm{CF}_{\mathrm{i}}: \text { Cash flows } \\
& \mathrm{r}_{\mathrm{i}} \quad \text { : real interest rate }
\end{aligned}
$$

The model used is based on the work of [14].

$$
\begin{aligned}
\mathrm{FPV}=\left(\overline{\mathrm{PV}}^{\alpha}, \underline{\mathrm{PV}}^{\alpha}\right)= & \frac{\left(\mathrm{pv}_{1}^{1(\alpha)}, \mathrm{pv}_{1}^{\mathrm{r}(\alpha)}\right)}{\left(1+\mathrm{r}_{1}\right)}+\frac{\left(\mathrm{pv}_{2}^{1(\alpha)}, \mathrm{pv}_{2}^{\mathrm{r}(\alpha)}\right)}{\left(1+\mathrm{r}_{1}\right)\left(1+\mathrm{r}_{2}\right)} \\
& +\ldots+\frac{\left(\mathrm{pv}_{7}^{1(\alpha)}, \mathrm{pv}_{7}^{\mathrm{r}(\alpha)}\right)}{\left(1+\mathrm{r}_{1}\right)\left(1+\mathrm{r}_{2}\right) \ldots\left(1+\mathrm{r}_{7}\right)}
\end{aligned}
$$

where

FPV : Fuzzy present value

$$
\begin{aligned}
& \left(\overline{\mathrm{PV}}^{\alpha}, \underline{\mathrm{PV}}^{\alpha}\right) \quad \text { : alpha-cut representation of present value } \\
& \mathrm{r}_{1}, \mathrm{r}_{2}, \ldots, \mathrm{r}_{7} \quad: \text { interest rate of each sub-period. }
\end{aligned}
$$

Using the mean and standard deviation of each sub-period, each fuzzy number is formed using proposed work by [15].

$$
P\left(X \in\left\lfloor x^{\text {mean }}-k \sigma, x^{\text {mean }}+k \sigma\right\rfloor \geq 1-1 / k^{2}\right.
$$

for

$$
k \geq 1
$$

\section{Results and Discussion}

This study portrayed one of the highway developments in Malaysia. The operation period is 26 years, divided into seven subperiods agreeing to the fluctuation of Malaysian GDP aligned with operation period. Only toll collection is considered, even so the parameter takes into consideration of risk of macroeconomic factor as stated in table 1 .

Table 2 illustrates mean and standard deviation of toll collection in seven sub-periods and the average real interest rate of each particular sub-periods. Here, real interest rate is considered as discount rate for the fuzzy present value model.

Table 2: Mean and Standard Deviation of Toll Collection and Real Interest Rate for Each Sub-periods

\begin{tabular}{|c|c|c|c|}
\hline & \multicolumn{2}{|c|}{ Toll Collection } & \multirow{2}{*}{$\begin{array}{c}\text { Int. Rate } \\
\text { (avg.) }\end{array}$} \\
\cline { 2 - 3 } & Mean & Std. Deviation & 5.21 \\
\hline 1. & 79958654 & 9118778 & 5.43 \\
\hline 2. & 78600630 & 5378469 & 5.43 \\
\hline 3. & 83217463 & 538926 & 1.24 \\
\hline 4. & 86225442 & 2931698 & 3.94 \\
\hline 5. & 90507411 & 3815439 & 1.40 \\
\hline 6. & 103017375 & 2681248 & 2.98 \\
\hline 7. & 112003404 & 2960607 & \\
\hline
\end{tabular}

Table 3 presents mean and standard deviation of toll collection into leftright presentation of triangular fuzzy number. The values also present macroeconomic risk that has comprised to observe the effect of the risk in the present value of toll collection.

Table 3: LR-presentation of Fuzzy Number

\begin{tabular}{|l|c|c|c|}
\hline & \multicolumn{3}{|c|}{ Toll Collection } \\
\cline { 2 - 4 } & Left & Mean & Right \\
\hline 1. & 11727008 & 15192144 & 18657280 \\
\hline 2. & 12890301 & 14934120 & 16977938 \\
\hline 3. & 15606526 & 15811318 & 16016110 \\
\hline 4. & 15268789 & 16382834 & 17496879 \\
\hline 5. & 15746541 & 17196408 & 18646275 \\
\hline 6. & 18554427 & 19573301 & 20592176 \\
\hline 7. & 20155616 & 21280647 & 22405678 \\
\hline
\end{tabular}




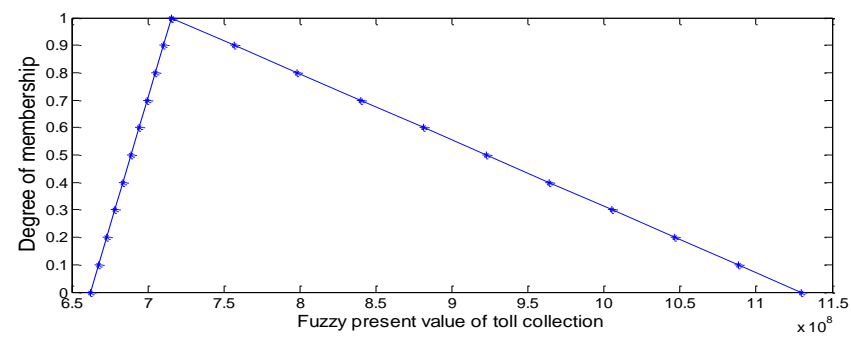

Fig. 1: Fuzzy present valuation of toll collection for 26 years operation period.

Figure 1 depicted fuzzy present value for 26 years of operation of the highway. Based on the result given, present value of the highway is in the range of $\left[6.6240 \times 10^{8}, 1.1295 \times 10^{9}\right]$. However, the most plausible present value of the highway estimated to be $7.0494 \times 10^{8}$. The estimated value also comprises macroeconomic risk that ascertains to anticipate in the highway development. The range of the estimated value will give sensible thought for the decision maker to make decision making based of the range given by the fuzzy present value of the project.

\section{Conclusion}

There are various numbers of risks associated with infrastructure development particularly in highway development. This study focuses on the impact of macroeconomic risk which particularly has significant impact to the toll highway collection. The estimated present value given can be employ by the decision maker to estimate the lucrative amount of profit from the development.

\section{References}

[1] Raja, K A R A K (2012), Malaysia's BOT Method Implementation For Highway Development Projects, Ritsumeikan Asia Pasific University.

[2] Bakri A, Saidan Khaderi S \& Abd AS (2009), Risk Management in Build-Operate-Transfer (BOT) for Roads and Highway Projects in Malaysia, Built Environ. J. 6(1), 1-11.

[3] Sarvari H, Valipuor A \& Yahaya N (2014), Risk Ranking of Malaysian Public Private Partnership Projects, Appl. Mech. Mater. 567, 613-618.

[4] Cooper DF, Grey S, Raymond G \& Walker P (2005), Managing Risk in Large Projects and Complex Procurements. John Wiley and Sons.

[5] Xu Y, Yeung JFY, Chan APC, Chan DWM, Wang SQ \& Ke Y (2010), Developing a risk assessment model for PPP projects in China-A fuzzy synthetic evaluation approach, Autom. Constr. 19(7), 929-943.

[6] Ebrahimnejad S, Mousavi SM \& Seyrafianpour H (2010), Risk Identification and Assessment for Build-Operate-Transfer Projects: A Fuzzy Multi Attribute Decision Making Model, Expert Syst. Appl. 37(1), 575-586.

[7] Ezanee F \& Ghazali M (2010), Operational Risks for Highway Projects in Malaysia, Int. J. Hum. Soc. Sci. 5(1), 22-25.

[8] Buckley JJ (1987), The Fuzzy Mathematics of Finance, Fuzzy Sets Syst. 21(1), 257-273.

[9] Yao JS, Chen MS \& Lin HW (2005), Valuation by Using a Fuzzy Discounted Cash Flow Model, Expert Syst. Appl. 28, 209-222.

[10] Wiesemann W, Kuhn D \& Rustem B (2010), Maximizing the Net Present Value of a Project Under Uncertainty, Eur. J. Oper. Res. 202(2), 356-367.

[11] Tsao CT (2012), Fuzzy Net Present Values for Capital Investments in an Uncertain Environment, Comput. Oper. Res. 39(8), 18851892.

[12] Dixit AK \& Pindyck RS (1994), Investment Under Uncertainty. Princeton University Press.

[13] Zadeh LA (1965), Fuzzy Set, Inf. Control 8, 338-353.

[14] Chiu C \& Park CS (1994), Fuzzy Cash Flow Analysis Using Present Worth Criterion, Eng. Econ. 39(2), 37-41.

[15] Dubois D, Foulloy L, Mauris G \& Prade H (2004), ProbabilityPossibility Transformations, Triangular Fuzzy Sets, and Probabilistic Inequalities, Reliab. Comput. 10, 273-297. 